\title{
Effect of osmo air drying method on nutritional quality of peach (Prunus persica (l) batsch.) cultivars during storage
}

\author{
Naseer Ahmed*, Jagmohan Singh, Babita', Anisa Malik, Harmeet Chauhan, Harleen \\ Kour and Prerna Gupta
}

Division of post harvest technology, Sher-e-Kashmir University of Agricultural Science and Technology, Udhywalla, Jammu-180001 (J\&K), INDIA

${ }^{1}$ Dr. Y.S. Parmar University of Horticulture and Forestry, Solan-173230 (H.P.), INDIA

* Corresponding author: E-mail: ewsjammu@gmail.com.

Received: September 24, 2015; Revised received: March 29, 2016; Accepted: July 11, 2016

Abstract: The present investigation was carried out with the objective to develop value added products and to assess the quality parameters of osmo air dried peach slices. The peach slices were dried by osmo air drying method. Dehydrated peach (Prunus persica (L) Batsch.) slices prepared were stored under ambient conditions in polythene packs and subjected to physico-chemical analysis at 45 days interval for a period of 135 days. The highest total sugars were observed in Flordasun $58.28 \%$ and reducing sugars $(39.35 \%)$ in Shan-e-Punjab. The maximum acidity $(1.84 \%)$ in Shan-e-Punjab, ash content (4.43\%) in Early Grand were recorded. The maximum ascorbic acid content of $11.94 \mathrm{mg} / 100 \mathrm{~g}$ was found in Shan-e-Punjab. During storage, an increasing trend was observed in total sugars $(54.27-56.76 \%)$ and reducing sugars (38.08-39.38\%), whereas, acidity (1.85-1.74), ascorbic acid (11.75$9.81 \mathrm{mg} / 100 \mathrm{~g}$ ), and ash content showed decreasing trend. It is thus concluded that Early Grand, Flordasun and Shan-e-Punjab, cultivars of peach can be suitably used for preparation of dehydrated peach product using osmo air drying methods.

Keywords: Cultivars, Nutritional quality, Osmo air drying, Peach, Storage

\section{INTRODUCTION}

Peach (Prunus persica (L) Batsch.) is believed to be the native of China. It is grown as a commercial and home fruit in most of the temperate countries of the globe. Extensive plantings of peaches occur in Turkistan and Persia. In Japan, peach is among the leading fruits. In USA, peach ranks second only to apple in commercial importance. Peach is grown around the world between $35^{\circ}$ and $40^{\circ}$ latitude in Asia, Europe, Africa and America (Watson, 1998). The world production of stone fruit is estimated to be about 25 million tonnes per annum, out of which peach contributes 13,757 million tonnes. In India, the introduction of sub -tropical peach started in 1968 , though the temperate varieties were already under cultivation in J\&K, H.P and U.P (Anonymous, 2011). In India, total production of peach was estimated to about 1,50,000 metric tonnes (FAO, 2006). During last decade cultivation of peach has given some encouraging results in subtropical areas of $\mathrm{J} \& \mathrm{~K}$.

Peach protects us from night blindness, dryness in the skin and formation of ulcer. The peach kernel oil is utilized in manufacturing of large number of cosmetics and pharmaceutical products. Due to seasonal gluts and highly perishable nature, considerable post harvest losses occurs at ambient temperatures. The availability of fruit (seasonal commodities) can be extended by the process of dehydration which acts as a preservation technique. The basic principle of dehydration is the removal of moisture through simultaneous heat and mass transfer, that provide more shelf-life, reduces weight and volume (Yaldiz, 2004). The aim of this work is to study the effect of drying methods viz. osmo air drying, on nutritional quality of dehydrated cultivars of peach during storage. Due to short shelf life of the peach they can be preserved by osmo air drying in order to increase the shelf life and make them available during off season. Osmotic dehydration involves the immersion of foods (fish, vegetables, fruits and meat) in osmotic solution such as salts, alcohols, starch solutions and concentrated sugars, which some extent to dehydrates the food (Erle and Schubert, 2001). Different types of solutes such as fructose, corn syrup, glucose, sodium chloride and sucrose are used as osmotic agent for osmotic drying (Azura and Beristain, 2002). Pretreatments like blanching and dipping the fruits in chemicals reduces the drying time and yield a good quality dried product (Piga et al., 2004). The present investigation was conducted to study the effect of osmo-air drying method on nutritional quality of peach (Prunus persica (L) Batsch.) cultivars during storage. 


\section{MATERIALS AND METHODS}

Three commercial cultivars of Peach viz., Shan-ePunjab, Flordasun and Early Grande were selected for the present study. The fruits were obtained from the orchards of Division of Fruit Science, Faculty of Agriculture, Sher-e-Kashmir university of Agricultural Science and Technology Jammu. Only mature and blemishes free fruits were selected for the study.

Pretreatments : The fruits were washed in water to remove adherent foreign materials and dust. Peach fruits were dipped in boiling lye solution $(2.0 \%$ $\mathrm{NaOH})$ for three minutes. The fruits were then washed thoroughly under tap water. Subsequently, fruits were dipped in $5.0 \%$ citric acid solution for five minutes to neutralize residual alkali from their surface.

Preparation of dehydrated slices: Peach fruits were cut into 4 to 6 pieces. The peach were spread on trays and dipped in sugar syrup $\left(60^{\circ}\right.$ Brix for $\left.24 \mathrm{hrs}\right)$ and then dried at $60 \pm 3^{\circ} \mathrm{C}$ in hot air oven. The final product was packed in 300 gauge polythene pouches and stored under ambient conditions for further studies.

Determination of titratable acidity : Titratable acidity was determined by titrating a known quantity of

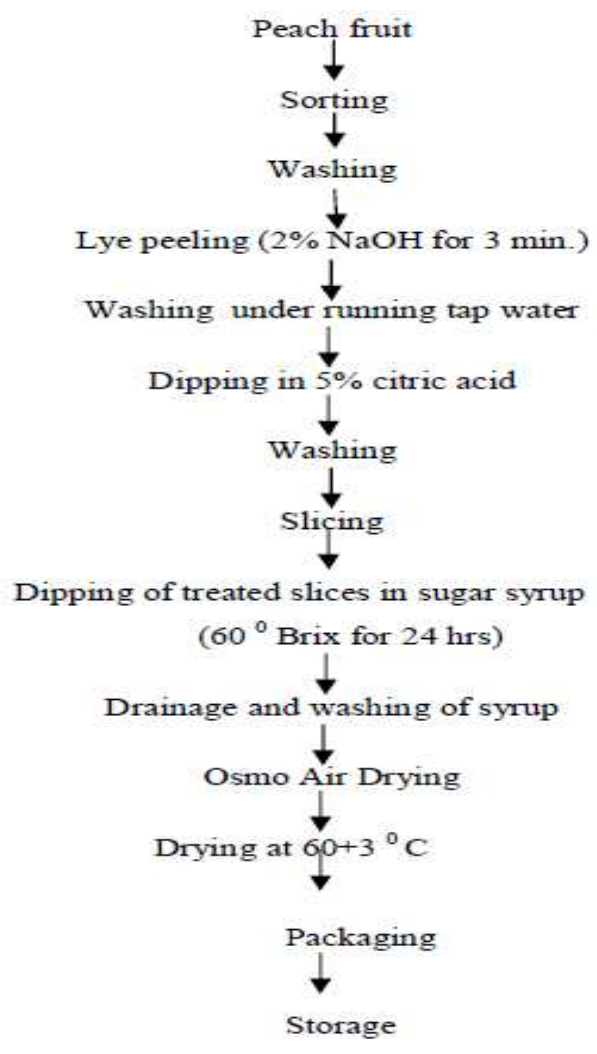

sample $(10 \mathrm{ml})$ against standard solution of $0.1 \mathrm{~N}$ sodium hydroxide to a faint pink colour using phenolphthalein as an indicator. The results were expressed as percent citric acid (Ranganna, 1986).

Determination of ascorbic acid: For estimation of ascorbic acid volumetric method is used. $10 \mathrm{~g}$ of sam- ple was taken and blended with $4 \%$ oxalic acid and volume was made up to $100 \mathrm{ml}$ with oxalic acid and filtered. Ten $\mathrm{ml}$ of the prepared sample was taken in a titration flask and titrated against standard dye(2, 6Dichlorophenol-indophenol) to a pink coloured endpoint, which persisted for at least 15 seconds. The results were expressed as $\mathrm{mg} / 100 \mathrm{~g}$ of sample.

Determination of sugars : Lane and Eynon (1923) method as detailed by Ranganna (1986) was followed to estimate the sugars in dried peach. Measured quantity of sample $(20 \mathrm{~g})$ was taken in $250 \mathrm{ml}$ volumetric flask to which $100 \mathrm{ml}$ distilled water was added and neutralized with 40 percent sodium hydroxide using phenolphthalein as indicator and clarified with $2 \mathrm{ml}$ neutral lead acetate (45\%) for about 30 minutes. Excess of lead was removed with $5 \mathrm{ml}$ potassium oxalate $(22 \%)$. The volume was made to $250 \mathrm{ml}$ and filtered through Whatman no. 4 filter paper. The filterate was titrated against $10 \mathrm{ml}$ of standardized Fehling's solution using methylene blue as an indicator to a brick-red precipitate for determination of reducing sugars. A measured aliquot $(100 \mathrm{ml})$ of the above filterate was taken in $250 \mathrm{ml}$ volumetric flask and was hydrolysed by adding $10 \mathrm{ml}$ of 50 percent hydrochloric acid, kept overnight, for $24 \mathrm{hrs}$ at room temperature followed by neutralization with 40 percent sodium hydroxide using phenolphthalein as an indicator. The volume was made to $250 \mathrm{ml}$ and titrated against Fehling's solution as above for total sugars.

Determination of ash: Ash content of sample was estimated by using standard method of AOAC (1995). Five grams sample was weighed and transferred in preweighed crucible and ignited it until no charred particles remained in the crucible. The crucible was then placed in muffle furnaces $\left(600^{\circ} \mathrm{C}\right)$ for $3 \mathrm{hrs}$. The crucible was cooled in desiccator and weighed to a constant weight. The difference between the weights of silica crucible with ash and as empty was the amount of total ash.

Determination of rehydration ratio : For estimation of rehydration ratio weighted samples of dehydrated peach were soaked in a beaker containing $100 \mathrm{ml}$ distilled water covered with watch glass and was made to boil for few minutes. The water was drained and the samples were air dried on filter paper and weighed again. The rehydration ratio was expressed as ratio of the weight of rehydrated product to the weight of dried product (Ranganna, 1986).

Determination of browning : The dehydrated samples were evaluated for browning by known method (Ranganna, 1986). A known quantity of sample (5g) was extracted with $60 \%$ alcohol $(20 \mathrm{ml})$ filtered and the absorbance of the filtrate was recorded at $440 \mathrm{~nm}$ using UV- spectrophotometer.

\section{RESULTS AND DISCUSSION}

Ascorbic acid: There was significant decrease in the ascorbic acid content in dehydrated peach during stor- 
Naseer Ahmed et al. / J. Appl. \& Nat. Sci. 8 (3):1214 - 1218 (2016)

Table 1. Effect of cultivar and storage on ascorbic acid $(\mathrm{mg} / 100 \mathrm{~g})$ and titratable acidity of osmo air dried peach slices.

\begin{tabular}{|c|c|c|c|c|c|c|c|c|}
\hline \multirow{3}{*}{$\begin{array}{l}\text { Storage } \\
\text { period } \\
\text { (Days) }\end{array}$} & \multicolumn{8}{|c|}{ Cultivars } \\
\hline & \multicolumn{4}{|c|}{ Ascorbic Acid } & \multicolumn{4}{|c|}{ Titratable acidity } \\
\hline & Shan-e-Punjab & $\begin{array}{c}\text { Early } \\
\text { Grande }\end{array}$ & $\begin{array}{l}\text { Flor- } \\
\text { dasun }\end{array}$ & Mean & $\begin{array}{l}\text { Shan-e- } \\
\text { Punjab }\end{array}$ & $\begin{array}{c}\text { Early } \\
\text { Grande }\end{array}$ & $\begin{array}{l}\text { Flor- } \\
\text { dasun }\end{array}$ & Mean \\
\hline 0 & 13.69 & 11.00 & 10.57 & 11.75 & 1.89 & 1.81 & 1.84 & 1.85 \\
\hline 45 & 12.25 & 10.76 & 10.29 & 11.10 & 1.85 & 1.79 & 1.81 & 1.82 \\
\hline 90 & 11.65 & 9.95 & 9.87 & 10.49 & 1.83 & 1.74 & 1.77 & 1.78 \\
\hline 135 & 10.15 & 9.65 & 9.64 & 9.81 & 1.78 & 1.71 & 1.72 & 1.74 \\
\hline Mean & 11.94 & 10.34 & 10.09 & & 1.84 & 1.76 & 1.79 & \\
\hline \multicolumn{2}{|l|}{ Factor } & \multicolumn{3}{|c|}{ C.D (5\%) } & \multicolumn{4}{|c|}{ C.D (5\%) } \\
\hline \multicolumn{2}{|l|}{ Treatment } & \multicolumn{3}{|c|}{0.08} & \multicolumn{4}{|c|}{0.04} \\
\hline \multicolumn{2}{|l|}{ Storage } & \multicolumn{3}{|c|}{0.09} & \multicolumn{4}{|c|}{0.07} \\
\hline \multicolumn{2}{|c|}{$\begin{array}{l}\text { Treatment } \times \text { Stor- } \\
\text { age }\end{array}$} & \multicolumn{2}{|c|}{0.17} & & \multicolumn{4}{|c|}{0.15} \\
\hline
\end{tabular}

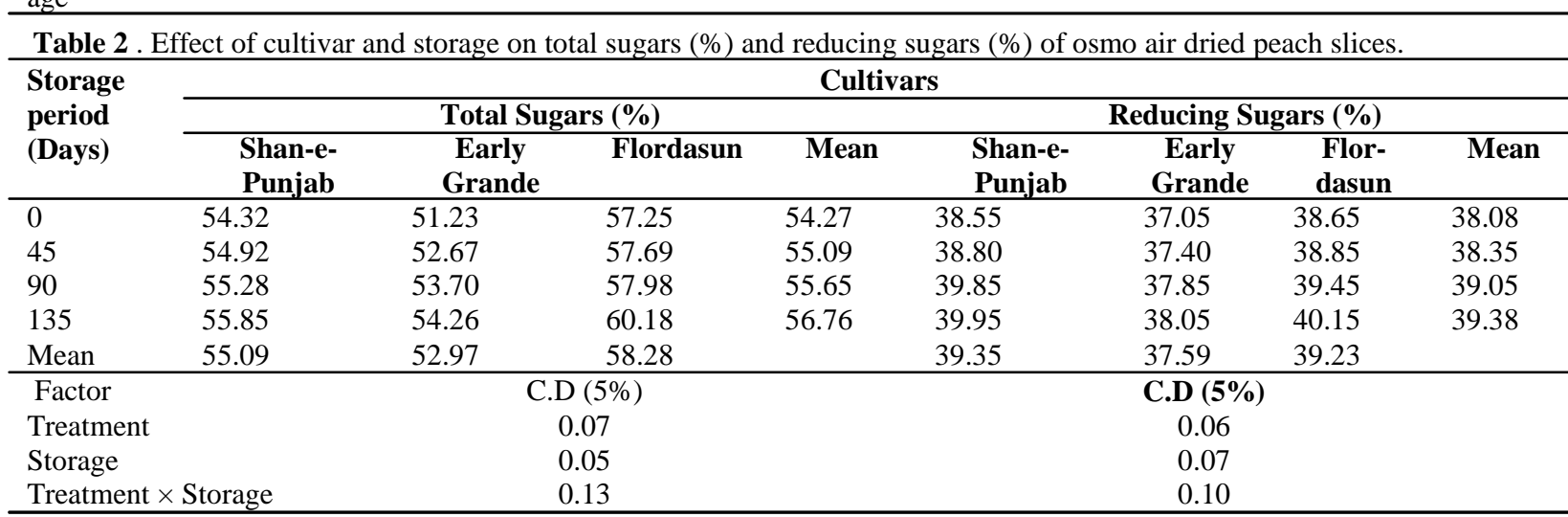

age period. At initial day of storage, the highest ascorbic acid content of (13.69 $\mathrm{mg} / 100 \mathrm{~g})$ was recorded in Shan-e-Punjab and lowest $(10.57 \mathrm{mg} / 100 \mathrm{~g})$ in Flordasun. After 135 days of storage the values decreased to $(10.15 \mathrm{mg} / 100 \mathrm{~g})$ in Shan-e-Punjab and 9.64 $\mathrm{mg} / 100 \mathrm{~g}$ in Flordasun. The decreasing trends in ascorbic acid during storage have also been reported by Rashmi et al. (2005) in osmo-dehydrated pineapple and Gupta (2007) in osmo-dehydrated ber. Muzzafer (2006) also reported the decreasing trend in ascorbic acid in pumpkin candy.

Titratable acidity: At the beginning of storage period, the highest titratable acidity of $1.89 \%$ was recorded in Shan-e-Punjab, whereas Early Grande recorded the lowest titratable acidity of $1.81 \%$. After 135 days of storage Shan-e-Punjab recorded the highest titratable acidity of $1.78 \%$. The decrease in titratable acidity might be due to utilization of acids for conversion of non-reducing sugars to reducing sugars. Reductions of titratable acidity during osmosis have also been reported by Gupta (2007) in ber churhara which could be assumed due to leaching of acids during osmosis. Kumar (2013) also reported the decreasing trend in the acidity osmo-dried plum during storage.

Total sugars: It is evident from Table 4 that treatments significantly influenced the total sugar content of dehydrated peach. Among the cultivars, Flordasun recorded the highest value of total sugars $57.25 \%$ followed by Shan-e-Punjab with total sugar content of $54.32 \%$ at initial day. After 135 days of storage, Flor-

Table 3. Effect of cultivar and storage on rehydration ratio and Ash content (\%) of osmo air dried peach slices.

\begin{tabular}{|c|c|c|c|c|c|c|c|c|}
\hline \multirow{3}{*}{$\begin{array}{l}\text { Storage } \\
\text { period } \\
\text { (Days) }\end{array}$} & \multicolumn{8}{|c|}{ Cultivars } \\
\hline & \multicolumn{4}{|c|}{ Rehydration ratio } & \multicolumn{4}{|c|}{ Browning (OD) } \\
\hline & Shan-e-Punjab & $\begin{array}{c}\text { Early } \\
\text { Grande }\end{array}$ & $\begin{array}{l}\text { Flor- } \\
\text { dasun }\end{array}$ & Mean & Shan-e-Punjab & $\begin{array}{c}\text { Early } \\
\text { Grande }\end{array}$ & Flordasun & Mean \\
\hline 0 & 2.95 & 3.10 & 2.75 & 2.93 & 0.81 & 0.79 & 0.76 & 0.79 \\
\hline 45 & 2.89 & 3.08 & 2.71 & 2.89 & 1.79 & 1.37 & 1.32 & 1.49 \\
\hline 90 & 2.83 & 3.01 & 2.67 & 2.84 & 2.60 & 2.04 & 2.01 & 2.22 \\
\hline 135 & 2.76 & 2.97 & 2.63 & 2.79 & 3.10 & 2.50 & 2.47 & 2.69 \\
\hline Mean & 2.86 & 3.04 & 2.69 & & 2.08 & 1.68 & 1.64 & \\
\hline \multicolumn{2}{|l|}{ Factor } & \multicolumn{3}{|c|}{ C.D (5\%) } & \multicolumn{4}{|c|}{ C.D (5\%) } \\
\hline \multicolumn{2}{|l|}{ Treatment } & \multicolumn{3}{|c|}{0.03} & \multicolumn{4}{|c|}{0.08} \\
\hline \multicolumn{2}{|l|}{ Storage } & \multicolumn{3}{|c|}{0.05} & \multicolumn{4}{|c|}{0.04} \\
\hline \multicolumn{2}{|c|}{ Treatment $\times$ Storage } & \multicolumn{3}{|c|}{0.07} & \multicolumn{4}{|c|}{0.09} \\
\hline
\end{tabular}


Table 4. Effect of cultivar and storage on moisture content (\%) and Ash content (\%) of osmo air dried peach slices.

\begin{tabular}{|c|c|c|c|c|c|c|c|c|}
\hline \multirow{3}{*}{$\begin{array}{l}\text { Storage } \\
\text { period } \\
\text { (Days) }\end{array}$} & \multicolumn{8}{|l|}{ Cultivars } \\
\hline & \multicolumn{4}{|l|}{ Moisture (\%) } & \multicolumn{4}{|l|}{$\operatorname{Ash}(\%)$} \\
\hline & Shan-e-Punjab & $\begin{array}{l}\text { Early } \\
\text { Grande }\end{array}$ & $\begin{array}{l}\text { Flor- } \\
\text { dasun }\end{array}$ & Mean & $\begin{array}{l}\text { Shan-e- } \\
\text { Punjab }\end{array}$ & $\begin{array}{l}\text { Early } \\
\text { Grande }\end{array}$ & Flordasun & Mean \\
\hline 0 & 19.70 & 17.10 & 21.07 & 19.29 & 4.18 & 4.68 & 4.42 & 4.43 \\
\hline 45 & 18.45 & 16.29 & 19.27 & 18.01 & 4.02 & 4.58 & 4.32 & 4.31 \\
\hline 90 & 17.30 & 15.37 & 18.95 & 17.21 & 3.86 & 4.28 & 4.24 & 4.13 \\
\hline 135 & 16.87 & 15.19 & 17.50 & 16.52 & 3.74 & 4.18 & 4.12 & 4.01 \\
\hline Mean & 18.08 & 15.99 & 19.20 & & 3.95 & 4.43 & 4.28 & \\
\hline \multicolumn{2}{|l|}{ Factor } & \multicolumn{3}{|c|}{ C.D (5\%) } & \multicolumn{4}{|c|}{ C.D (5\%) } \\
\hline \multicolumn{2}{|l|}{ Treatment } & \multicolumn{3}{|c|}{0.11} & \multicolumn{4}{|c|}{0.07} \\
\hline \multicolumn{2}{|l|}{ Storage } & \multicolumn{3}{|c|}{0.03} & \multicolumn{4}{|c|}{0.10} \\
\hline \multicolumn{2}{|c|}{ Treatment $\times$ Storage } & \multicolumn{3}{|c|}{0.21} & \multicolumn{4}{|c|}{0.19} \\
\hline
\end{tabular}

dasun recorded highest value of $60.18 \%$ followed by Shan-e-Punjab having total sugar content of $55.85 \%$.

The total sugar content of dehydrated peach increased significantly during the entire storage period from initial mean value of 54.27 to $56.76 \%$. The increase might also be attributed to hydrolysis of starch in to sugars (Roy and Singh, 1979). Gupta (2007) and Sharma et al. (2006) also observed significant increase in total sugars in osmo-dehydrated ber and apricot during storage. Reducing sugars : During storage, the reducing sugars content of dehydrated peach increased significantly with the advancement in storage period from initial mean value of 38.08 to $39.38 \%$. At initial day the highest value of reducing sugar $38.65 \%$ was recorded in Flordasun and lowest $37.05 \%$ in Early Grande. After 135 days of storage period, Flordasun recorded highest value of $40.15 \%$ whereas; Early Grande showed lowest value of sugar content of $38.05 \%$. This increase in reducing sugars during storage might be due to inversion of non-reducing sugars to reducing sugars. The results are in accordance with those obtained by Amitabh et al. (2000) in mango slices found that during storage the reducing sugar increase from 0 day to 90 days, Muzzaffer (2006) in pumpkin candy, Naikwadi et al. (2010) also reported increasing trend in reducing sugars in dehydrated fig.

Rehydration ratio: The rehydration ratio of dehydrated peach was observed to decrease from 2.93 to 2.79 during storage. Among the cultivars, Early Grande recorded the highest value 3.10 and lowest 2.75 was recorded in Flordasun at initial day. After 135 days of storage Early Grande recorded maximum rehydration ratio of 2.97 and minimum rehydration ratio was recorded in Flordasun having value of 2.63. Similar trend of decrease of rehydration ratio was observed by Tomar et al. (1985) in dehydrated mixed vegetable pickle after 12 months of storage. Alkesh (2001) also found similar trend of decrease of rehydration ratio in dehydrated apple rings.

Browning: Maximum optical density (OD) which is index of browning of 0.81 was observed in Shan-ePunjab and minimum 0.76 was observed in Flordasun at the initial day. After 135 days of storage Shan-e-
Punjab recorded the highest optical density 3.10 minimum optical density 2.47 was recorded in Early Grande. The increase in browning might be due to wide range of residual peroxidases, ployphenoloxidases and lipooxigenase even after blanching, as in green peas (Helpin and Lee, 1987). An increase in nonenzymatic browning of date candy was also noticed when stored at room temperature for 60 days (Kumar, 1989).

Moisture : At the beginning of storage period, the highest moisture content of $21.07 \%$ was recorded in Flordasun and lowest of $17.10 \%$ in Early Grande. As the storage advances the highest moisture content was recorded $17.50 \%$ in Flordasun and lowest $15.19 \%$ in Early Grande. The mean values of storage period showed decrease from initial value of 19.29 to $16.52 \%$ after 135 days of storage. The decrease in moisture content might be due to natural dehydration of product during storage at room temperature. Similar trend has been reported by Chavan et al. (2010). These findings were in conformity with the findings of Gupta et al. (1980) in ber and Mehta et al. (2005) reported moisture content decreases with an increase in storage period lemon peel waste candy.

Ash: The ash content of different cultivars decreased significantly during storage. The Early Grande recorded highest value of ash content $4.68 \%$ followed by $4.42 \%$ in Flordasun and the lowest value $4.18 \%$ was recorded in Shan-e-Punjab. At the end of storage period the Early Grande recorded the highest ash content of $4.18 \%$ followed by $4.12 \%$ in Flordasun. The lower ash content is due to increased activities of microorganism utilizing the minerals for growth. Further, the rate of decrease of ash content was more pronounced at ambient temperatures than at cold temperatures (Ashaye et al. 2006). Das and Dutta (2013) reported total ash content in the range between $2.32 \%$ to $3.29 \%$ in dried ber.

\section{Conclusion}

It was concluded that Early Grand, Flordasun and Shan-e-Punjab, cultivars of peach can be suitably used for preparation of dehydrated peach product using osmo air drying methods. The storability study revealed that osmo dehydrated peach have good shelf 
life and can be kept for more than 135 days without affecting the quality attributes.

\section{REFERENCES}

Alkesh, (2001). Evaluation of some low chilling apple cultivars for dehydration and development of dehydrated fruit based products. M.Sc. thesis, Dr. Y.S. Parmar University of Horticulture and Forestry, Nauni, Solan, Himachal Pardesh, India

AOAC. (1995). Official methods of analysis of $15^{\text {th }}$ edition. Association of Analytical Chemists, Washington, D.C.

Azura, E and C.I. Beristain. (2002). Osmotic dehydration of apples by immersion in concentrated sucrose/ maltodextrin solution. Journal of Food Processing Preservation, 26:295-306.

Amitabh., Singh, R.D. and M.C. Tomar, (2000). Studies on osmotic dehydration of some varieties of ripe mangoes grown in Uttar Pardesh. Indian Food Packer, 66-71.

Anonymous, (2011). Annual area and production report. Department of Horticulture, Jammu, Jammu and Kashmir.

Ashaye, O. A., Taiwo, O. O. and G. O. Adegoke, (2006). Effect of local preservatives on the chemical and sensory properties of stored warakanshi. African Journal of Agricultural Research, 1(1): 10-16.

Chavan, U.D., Prabhukhanolkar, A.E. and V.D. Pawar, (2010). Preparation of osmotic dehydrated ripe banana slices. Journal of Food Science and Technology, 47(4): 380-386.

Das, P. and S. Dutta, (2013). A comparative study on drying of ber. Journal of Agricultural Engineering, 50(1): 34-38.

Erle, U. and H. Schubert. (2001). Combined osmotic and microwave-vacuum dehydration of apples and strawberries. Journal of Food Engineering. 49:193-199.

FAO, (2006). Statistical database of Food and Agricultural Organisation, FAO, Rome Italy.

Gupta, N. (2007). Studies on processing and preservation of ber. Ph.D. thesis, Sher-e-Kashmir University of Agricultural Science and Technology of Jammu, India.

Gupta, O.P., Kainsa R. L. and K. S. Chauhan, (1980). Post harvest study in ber. (Ziziphus mauritiana Lamk.). Journal of Research, 10(2): 163-165.

Helpin, B.E. and C.Y. Lee, (1987). Effect of blanching on enzyme activity and quality changes in green peas. Journal of Food Science, 52(4):1002.
Kumar, S. (1989). Studies on the processing of date palm fruit. M. Sc. thesis Chaudhary Charan Singh Haryana Agricultural University, Hisar, India.

Kumar, N.(2013). Optimization of method for preparation of osmo-dried plum (Prunus saliciana L.). M.Sc. thesis, Dr. Yashwant Singh Parmar University of Horticulture and Forestry, Solan (H.P).

Lane, J.H. and S.Eyon, (1923). Determination of reducing sugars by Feheling's solution with methyl blue as indicator. Journal of Society and Chemistry of India, 32-42.S

Mehta, A., Ranote, P. S. and A.S. Bawa, (2005). Processing of kandi lemon ( Galgal) peel waste for candy making. Indian Food Packer, 59(1): 21-23.

Muzzaffer, S. 2006. Utilization of pumpkin (Cucurbita moschata) for preparation of value added products. M.Sc. thesis, Dr. Yashwant Singh Parmar University of Horticulture and Forestry, Solan (H.P).

Naikwadi, P.M., Chavan, U.D., Pawar, V.D. and R. Amarowicz, (2010). Studies on dehydration of fig using different sugar syrup treatment. Journal of Food Science and Technology, 47(4): 442-445.

Piga, A., Pinna, I., Ozer, K.B., Agabbio, M. and U. Aksoy, (2004). Hot air dehydration of figs (Ficus carica L.): drying kinetics and quality loss. International Journal of Food Science and Technology, 39: 793-799.

Rashmi, H.B., Gowda, D.I.M. and G.K. Mukenda, (2005). Studies on osmo-air dehydration of pineapple fruits. Journal of Food Science and Technology, 42(1): 64-67.

Ranganna, S. 1986. Manual of Analysis of Fruits and Vegetable Products. Tata McGraw Hill Publishing Company Ltd. New Delhi.

Roy, S.K. and Singh, R. N. 1979. Studies on utilization of bael fruit (Aegle marmelos) for processing. Indian Food Packer, 33: 9-14.

Sharma, H.R., Handa,P. and R. Verma, (2006). Organoleptic and chemical evaluation of osmotically processed apricot wholes and halves. Natural Product Radiance, 5(5): 350-356.

Tomar, M.C. and B.S. Gawar, (1985). Studies on dehydration of muskmelon. Indian Food Packer, 39(5): 47-55.

Watson, W. (1998). The gardeners assistance; an encyclopedia of horticulture, Biotech Books, New Delhi, Vol. 2: pp 141.

Yaldiz, I. (2004). Drying characteristics and kinetics of okra. Journal of Food Engineering, 69: 275-279. 